\title{
Algae Biofuels Production Processes, Carbon Dioxide Fixation and Biorefinery Concept
}

Sara P Cuellar-Bermudeza, Miguel Angel Romero-Ogawaa, Bruce E. Rittmannb, Roberto Parra-Saldivara*

Catedra de Bioprocesos Ambientales, Centro del Agua Para America Latina y el Caribe. Instituto Tecnologico y de Estudios Superiores de Monterrey. Av. Eugenio Garza Sada 2501, Monterrey, Nuevo Leon, Mexico

\begin{abstract}
Microalgae are photosynthetic microorganisms capable to produce lipids, carbohydrates, and proteins as major biomass fractions. Each of these have been studied to produce biofuels. As example biodiesel, bioethanol, biogas, bio-oil and biohydrogen by different processes and conditions. In addition, microalgae are considered an alternative for $\mathrm{CO}_{2}$ emissions fixation since this gas is used by their metabolism. Based on this sustainable alternative, microalgae are considered feedstock to integrate a Bio-refinery, in which different products can be obtained from biofuels to food. In this article, in addition to the literature revision for biofuels production from microalgae, drawbacks and bottlenecks from microalgae technologies are discussed.
\end{abstract}

Keywords: Microalgae; Biofuels; $\mathrm{CO}_{2}$ fixation; Bio-refinery

\section{Introduction}

Microalgae are the largest autotrophic microorganisms from plant taxa living in the Earth [1]. They use solar energy, nutrients and $\mathrm{CO}_{2}$ to produce lipids, proteins, carbohydrates and other valuable organic compounds as pigments [2,3]. Microalgae growth takes place by photoautotrophic (inorganic carbon as $\mathrm{CO}_{2}$, light and nutrients) or heterotrophic (organic carbon, light absent) production. However some algae strains can combine autotrophic photosynthesis and heterotrophic assimilation of organic compounds in a mixotrophic process $[4,5]$.

Microalgae can serve as an alternative biofuel feedstock due to their rapid growth rate, greenhouse gas fixation ability and high lipid production capacity [6]. Moreover, the whole algal biomass or algae extracts can be converted into different fuel forms like biogas, liquid and gaseous transportation fuels as kerosene, ethanol, jet fuel, and hydrogen through the implementation of processing technologies such as anaerobic digestion, pyrolysis, gasification, catalytic cracking, enzymatic or chemical transesterification $[7,8]$. However, these processes are complex, technologically challenging and economically expensive [6].

In this article, different biofuels technologies from algae are described. Also, the utilization of algae cultures as an alternative to $\mathrm{CO}_{2}$ emissions reduction is described. Finally, an evaluation of challenges that algae production currently face is related.

\section{$\mathrm{CO}_{2}$ Capture}

Current anthropogenic activities deliver high amounts of greenhouse gases (GHG) emissions to the atmosphere contributing to global warming (GW). Transportation and energy sectors are the major source of greenhouse gasses (GHG) emissions [9]. In addition, global consumption of coal and natural gas are responsible for about $40 \%$ and $20 \%$ of total $\mathrm{CO}_{2}$ emissions respectively.

According to Yang et al., [10] there are three options to reduce total $\mathrm{CO}_{2}$ emission into the atmosphere: (1) reducing energy intensity use, (2) reducing carbon intensity use, and (3) enhancing the sequestration of $\mathrm{CO}_{2}$. The first option requires efficient use of energy; the second one refers to the use of non-fossil fuels and the third option involves technologies to capture and reuse the $\mathrm{CO}_{2}$. These capture methods are post-combustion, pre-combustion, oxy-combustion and chemical looping combustion [11].

In post-combustion capture, different methods are commonly used: chemical adsorption by zeolite, activate carbon, amine adsorbents and metal organic frameworks; chemical absorption by aqua ammonia, dual-alkali and sodium carbonate slurry; cryogenic distillation by $\mathrm{CO}_{2}$ de-sublimation and gas separation membrane by polymeric, inorganic and matrix membranes. Post-combustion capture refers to the capture of $\mathrm{CO}_{2}$ from the synthesis gas stream before combustion. The $\mathrm{CO}$ present in the syngas is converted to $\mathrm{CO}_{2}$ (by water reaction), to form a gas stream mainly composed of $\mathrm{CO}_{2}$ and $\mathrm{H}_{2}$. Later, the $\mathrm{CO}_{2}$ is recovered and the $\mathrm{H}_{2}$ is used as fuel. In case of oxy-combustion, the fuel is combusted with $\mathrm{O}_{2}$ and $\mathrm{CO}_{2}$, producing emissions with concentrated $\mathrm{CO}_{2}(75-80 \%)$ and water vapor. Finally, chemical looping combustion (CLC) refers to the use of oxygen carriers (metal oxides) in two fluidized bed reactors. In this system fuel and combustion air never are in contact. The result is one stream of $\mathrm{CO}_{2}$ and water and other with $\mathrm{N}_{2}$ and $\mathrm{O}_{2}$ [11]. Besides challenging, technology needs and cost are high. In case of post-combustion the $\mathrm{CO}_{2}$ partial pressure should be $3-20 \%$ with low temperature, $\mathrm{NO}_{\mathrm{x}}, \mathrm{SO}_{\mathrm{x}}$ and particulate matter, while oxy-combustion is the most expensive method [11].

Microalgae are considering the fourth alternative to reduce $\mathrm{CO}_{2}$ by biological $\mathrm{CO}_{2}$ fixation [9]. This process is currently achieved through the photosynthesis of all terrestrial plants and a tremendous number of photosynthetic microorganisms [12]. However, plants are expected to contribute only with a 3-6\% reduction of global $\mathrm{CO}_{2}$ emissions [13]. Therefore, since years ago, researches have focus in the evaluation of microalgae [14] since they can grow much more faster than terrestrial

*Corresponding author: Roberto Parra-Saldivar, Catedra de Bioprocesos Ambientales, Centro del Agua Para America Latina y el Caribe. Instituto Tecnologico y de Estudios Superiores de Monterrey. Av. Eugenio Garza Sada 2501, Monterrey, Nuevo Leon, Mexico, Tel: +52 (81) 8155 2573; E-mail: r.parra@itesm.mx

Received July 08, 2014; Accepted August 18, 2014; Published August 25, 2014

Citation: Cuellar-Bermudez SP, Romero-Ogawa MA, Rittmann BE, Parra-Saldivar R. Algae Biofuels Production Processes, Carbon Dioxide Fixation and Biorefinery Concept. J Pet Environ Biotechnol 5: 185. doi:10.4172/2157-7463.1000185

Copyright: (c) 2014 Cuellar-Bermudez SP, et al. This is an open-access article distributed under the terms of the Creative Commons Attribution License, which permits unrestricted use, distribution, and reproduction in any medium, provided the original author and source are credited. 


\begin{tabular}{|c|c|c|}
\hline Species & Product & Yield \\
\hline \multirow[t]{4}{*}{ Chlamydomonas reinhardtii (CC124) } & \multirow[t]{12}{*}{ Biohydrogen } & $102 \mathrm{~mL} / 1.2 \mathrm{~L}$ \\
\hline & & $0.58 \mathrm{~mL} / \mathrm{hL}$ \\
\hline & & $0.30 \mathrm{~mol} / \mathrm{m}^{2}$ \\
\hline & & $0.6 \mathrm{~mL} / \mathrm{L} \mathrm{h}$ \\
\hline \multirow{3}{*}{$\begin{array}{l}\text { Chlamydomonas reinhardtii (Dang } 137 \mathrm{C} \\
\mathrm{mt}+\text { ) }\end{array}$} & & $175 \mathrm{~mL} / \mathrm{L}$ \\
\hline & & $4.5 \mathrm{mmol} / \mathrm{L}$ \\
\hline & & $71 \mathrm{~mL} / \mathrm{L}$ \\
\hline Chlorella vulgaris MSU 01 & & $26 \mathrm{ml} / 0.5 \mathrm{~L}$ \\
\hline Scenedesmus obliquus & & $3.6 \mathrm{ml} / \mu \mathrm{g} \mathrm{Chl} \mathrm{a}$ \\
\hline \multirow[t]{3}{*}{ Platymonas subcordiformis } & & $11,720 \mathrm{~nL} / \mathrm{h}$ \\
\hline & & $7.20 \mathrm{~mL} / \mathrm{h}$ \\
\hline & & $0.339 \mathrm{~mL} / \mathrm{hL}$ \\
\hline \multirow[t]{3}{*}{ Dunaliella tertiolecta } & \multirow[t]{8}{*}{ Bio-oil } & $43.8 \%, 34 \mathrm{MJ} / \mathrm{Kg}$ \\
\hline & & $42.6 \%, 37.8 \mathrm{MJ} / \mathrm{Kg}$ \\
\hline & & $25.8 \%, 30.74 \mathrm{MJ} / \mathrm{Kg}$ \\
\hline \multirow[t]{2}{*}{ Chlorella protothecoides } & & $52 \%$ \\
\hline & & $57.9 \%$ \\
\hline Chlorella sp & & $28.6 \%$ \\
\hline Chlorela vulgaris & & $35.83 \%$ \\
\hline Nannochloropsis sp. & & $31.1 \%$ \\
\hline Chlorella vulgaris & \multirow[t]{7}{*}{ Biogas } & $0.63-0.79 \mathrm{LCH}_{4} / \mathrm{gVS}$ \\
\hline Dunaliella salina & & $0.68 \mathrm{LCH}_{4} / \mathrm{gVS}$ \\
\hline Euglena graciis & & $0.53 \mathrm{LCH}_{4} / \mathrm{gVS}$ \\
\hline Scenedesmus & & $140 \mathrm{LCH}_{4} / \mathrm{KgVS}$ \\
\hline $\begin{array}{l}\text { Scenedesmus (Biogas from lipid-free } \\
\text { biomass) }\end{array}$ & & $212 \mathrm{LCH}_{4} / \mathrm{KgVS}$ \\
\hline $\begin{array}{l}\text { Scenedesmus (Biogas from amino acids- } \\
\text { free biomass) }\end{array}$ & & $272 \mathrm{LCH}_{4} / \mathrm{KgVS}$ \\
\hline Scenedesmus obliquus & & $0.59-0.69 \mathrm{LCH}_{4} / \mathrm{gVS}$ \\
\hline Botryococcus braunii & \multirow{12}{*}{$\begin{array}{l}\text { Lipid content } \\
\text { for Biodiesel }\end{array}$} & $25-75 \%$ \\
\hline Chlorella sp. & & $28-32 \%$ \\
\hline Chlorella vulgaris & & $56 \%$ \\
\hline Crypthecodinium cohnii & & $20 \%$ \\
\hline Monallanthus salina & & $20-70 \%$ \\
\hline Nannochlorisis $s p$ & & $20-35 \%$ \\
\hline Nannochloropsis sp & & $31-68 \%$ \\
\hline Neochloris oleoabundans & & $35-54 \%$ \\
\hline Nitzschia sp & & $45-47 \%$ \\
\hline Scenedesmus dimorphus & & $6-40 \%$ \\
\hline Scenedesmus obliquus & & $11-55 \%$ \\
\hline Schizochytrium sp. & & $77 \%$ \\
\hline Chlorella pyrenoidosa & \multirow{6}{*}{$\begin{array}{l}\text { Carbohydrates } \\
\text { content for } \\
\text { Bioethanol }\end{array}$} & $26 \%$ \\
\hline Chlorella vulgaris & & $12-17 \%$ \\
\hline Dunaliella salina & & $32 \%$ \\
\hline Scenedesmus obliquus & & $10-17$ \\
\hline Porphyridium cruentum & & $40-57 \%$ \\
\hline Euglena gracilis & & $14-18 \%$ \\
\hline
\end{tabular}

Table 1: Biofuels yields from algae $[7,32-38]$

plants, and their $\mathrm{CO}_{2}$-fixation efficiency compared with higher plants is about 10-50 times higher [15]. Microalgae from water bodies currently fix $\mathrm{CO}_{2}$ from the atmosphere. Therefore, microalgae cultivation have been proposed to fix $\mathrm{CO}_{2}$ emitted from power plants. Nevertheless, feeding emissions from power plants to algae culture is still in research and develop due to the challenges previously commented. In addition, it is desirable that the microalgae species have high growth and $\mathrm{CO}_{2}$ utilization rates, tolerance to flue gases constituents (SOx and NOx), production of valuable products and co-products (biodiesel and biomass for solid fuels), simplicity in harvesting (settling or bioflocculation), high water temperature tolerance (to minimize cost of cooling exhaust flue gases), and possible coupling with wastewater treatment [5].

\section{Biofuels}

The principal biofuels are bioethanol, biodiesel, bio-hydrogen, and biogas [8]. The biofuels sector includes alcohols (derived from sugars fermentation or conversion of cellulosic biomass through a combination of hydrolysis and fermentation or gasification and synthesis), traditional biodiesel (mono-alkyl esters made from transesterification of vegetable or animal triglycerides), and synthesis fuels of alcohols and alkanes (gasoline, diesel, etc.) produced from gasification of biomass, Fischer-Tropsch synthesis or others thermochemical processes [16] In Table 1 are shown results from biofuels produced from algae. In addition, diverse possible biofuels from algae are described:

\section{Biodiesel}

Biodiesel has a significant potential use as alternative fuel in compression-ignition (diesel) engines [17,18]. It is technically competitive with conventional petroleum-derived diesel fuel and requires no changes in the fuel distribution infrastructure [19]. Biodiesel is also biodegradable, nontoxic and with a favorable combustion emission profile, producing much less carbon monoxide, sulfur dioxide and unburned hydrocarbons than petroleum-based diesel fuel [8,20-24].

Algae lipids react by transesterification to produce biodiesel. Transesterification reaction of triglycerides with an alcohol in presence of a catalyst produces fatty acid chains (biodiesel) and glycerol $[20,25,26]$. Methanol, ethanol, propanol, butanol are common alcohols used for transesterification reaction [23]. Limitations in the transesterification reaction are mainly due to oil impurities, reaction conditions (time and temperature) and catalyst nature (acid, basic, enzymes) [27,28]. Transesterification using methanol and ethanol produces Fatty Acid Methyl Esters (FAME) and Fatty Acid Ethyl Esters (FAEE), respectively. Methanol is preferred for been more economic and have lower reaction times compared with higher alcohol molecules. The stoichiometry of reaction requires $3 \mathrm{~mol}$ of methanol and $1 \mathrm{~mol}$ of triglyceride to give $3 \mathrm{~mol}$ of FAME and $1 \mathrm{~mol}$ of glycerol [29]. For a maximum performance, this ratio must be greater than the stoichiometric ratio since the reaction is reversible. Therefore, an excess of alcohol shift the equilibrium to the product side.

For biodiesel production, algae species with high amount of lipids are preferred. However, lipid production in microalgae mainly depends on the algae species, and it is affected by culture growth conditions, such as nutrients, salinity, light intensity, temperature, $\mathrm{pH}$, and even, the association with other microorganisms. Nitrogen limitation is considered the most efficient strategy to increase the content of neutral lipids in algae, in particular formed by triglycerides with a high degree of saturation. However, this method produces a decrease in biomass productivity. In contrast, high light intensity and therefore high temperature, favor the accumulation of triglycerides substantially with high saturation profile. Meanwhile, low light intensities and temperature promote the synthesis of polyunsaturated fatty acids (PUFAs) [30]. Lipids quantity and composition are key properties that determine biodiesel oxidative stability and performance properties. In order to produce a biodiesel of high quality, the following fatty acid profiles are desirable [31]: (1) Lowest possible saturated fatty acid levels (such as C16:0 and C18:0) for improved winter operability, (2) highest possible monounsaturated fatty acid levels (such as C18:1) for good stability and winter operability and (3) lowest possible polyunsaturated fatty acids levels (such as C18:3) to increase oxidation stability. 


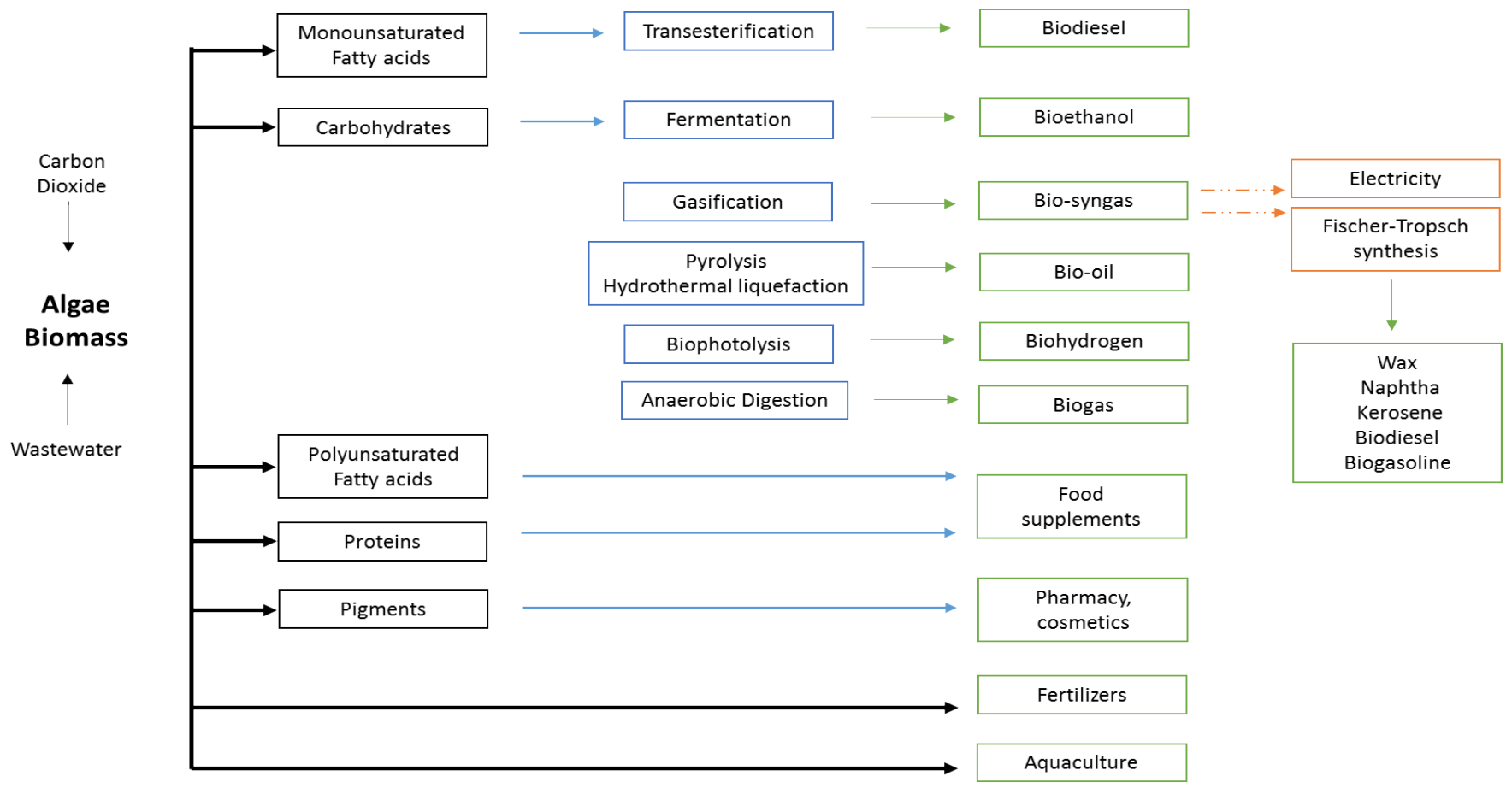

Figure 1: Different Algae Processes for Biofuels and High Value Compounds Production by the Bio-refinery Concept.

\section{Bioethanol}

Fermentation is used commercially on large scale in various countries to produce ethanol from sugar crops and starch crops [38]. Some microalgae are known to contain a large amount ( $>50 \%$ of the dry weight) of starch, cellulose and glycogen, which are raw materials for ethanol production. Also, the absolute or near absence of lignin makes the enzymatic hydrolysis of algal cellulose very simple [7]. For ethanol production, pretreatment of biomass is needed to release the carbohydrates contained in the cells later, fermentation of this carbohydrates occurs producing ethanol. Finally, separation and purification by distillation is required [38,39]. Microalgae by starch degradation during anaerobic metabolism can also produce ethanol [36].

\section{Biogas}

Biogas or bio-methane is the fuel produced by anaerobic digestion of organic matter. Biogas is mainly formed by methane from 55 to $75 \%$ and $\mathrm{CO}_{2}$ from 25 to $45 \%$ [36]. Algae have been proposed as feedstock for this type of fuel $[7,40]$. However, it has also been reported that low biogas formation yields are due to the resistibility of algae cell walls to bacteria degradation and to the low carbon to nitrogen $(\mathrm{C} / \mathrm{N})$ ratio microalgal species allowing ammonia formation (inhibitor) [41-43]. Anaerobic digestion occurs in four stages: (a) hydrolization of biopolymers to mono-saccharides by hydrolytic bacteria, (b) fermentation of mono-saccharides to carboxylic acids and acids (c) formation of acetate, hydrogen and carbon dioxide by acetogenic bacteria (d) formation of carbon dioxide and methane by methanogenic bacteria [36].

Ramos-Suárez and Carreras [37] evaluated Scenedesmus lipid-free and amino acids-free residues for biogas production. Results showed that biomass substrate free of lipids and amino acids produced higher methane yield compared to raw biomass. Also, the authors proposed the use of co-substrates with higher $\mathrm{C} / \mathrm{N}$ ratio than microalgae; however results did not show an increment of methane production. Therefore, for biogas production, algae residues are preferred.

\section{Biosyngas}

Biomass gasification in presence of oxygen, water vapor or air, produces carbon monoxide, hydrogen, methane, water, other hydrocarbons and ashes, the product is called synthetic gas or syngas. High temperatures are needed for gasification $\left(800\right.$ to $\left.1200^{\circ} \mathrm{C}\right)$ and water content in the biomass feedstock should not be higher than $20 \%$ [44]. Later, the syngas can be burned in turbines and boilers to produce electricity, or for the Fischer-Tropsch synthesis (FTS). From this last reaction wax, nafta, kerosene, diesel and gasoline can be obtained [9].

\section{Biohydrogen}

Hydrogen is the fuel with the highest energy content per unit weight compared with other fuels $(142 \mathrm{KJ} / \mathrm{g})$ [33]. In case of algae, biohydrogen metabolic production occurs by direct (Ec. 1) or indirect photolysis (Ec. 2, Ec. 3) as follows [33,36]:

$$
\begin{aligned}
& 2 \mathrm{H}_{2} \mathrm{O} \rightarrow \text { Light } \rightarrow 2 \mathrm{H}_{2}+\mathrm{O}_{2} \\
& 12 \mathrm{H}_{2} \mathrm{O}+6 \mathrm{CO}_{2} \rightarrow \text { Light }+\mathrm{C}_{6} \mathrm{H}_{12} \mathrm{O}_{6}+6 \mathrm{O}_{2} \\
& \mathrm{C}_{6} \mathrm{H}_{12} \mathrm{O}_{6}+12 \mathrm{H}_{2} \mathrm{O} \rightarrow 12 \mathrm{H}_{2}+6 \mathrm{CO}_{2}
\end{aligned}
$$

In algae, nitrogenases and hydrogenases enzymes are related to hydrogen production [36]. Both enzymes are oxygen sensitive, therefore cultures conditions should be controlled for hydrogen production [36]. Nitrogen starvation is often used at the end of the growth stage as an efficient metabolic stress to induce the activity of nitrogenase [44]. Also, sulfur deprivation enhances the inactivation of photosynthetic water oxidizing activity, catalyzed by the reaction center of photosystem two (PSII) [36]. In case of direct photolysis absence of oxygen is required, while in indirect photolysis, microalgae first produce hydrates to later 
produce carbohydrates by dark anaerobic mechanism [44]. Some algae species used for biohydrogen production are: Chlamydomonas reinhardtii, Scenedesmus obliquus, Chlorococcum litorale and Platy Monas subcordiformis [44].

\section{Bio-oil}

Thermochemical conversion of microalgae occurs by pyrolysis and hydrothermal liquefaction. In both processes, an aqueous, gaseous and solid (char) fraction are obtained $[35,40,45]$. For the thermochemical processes, algae fresh or residual biomass (after extraction of lipids, proteins, carbohydrates) can be converted to bio-oil.

Hydrothermal liquefaction (HTL) process' advantage is that algae biomass does not need to be dry ( $80 \%$ water content) [45]. Process conditions range at temperature from 250 to $360^{\circ} \mathrm{C}$ with high pressure (10-30 MPa) to maintain the water in the liquid phase $[35,45,46]$. However, bio-oils from HTL are more viscous and have higher oxygen content than petroleum diesel crude oil, therefore, refining steps like hydrodeoxygenation, hydrotreating and hydrocracking, have been proposed [46]. Hydrocracking produces diesel fuel, while catalytic cracking produces gasoline [44].

In case of pyrolysis, bio-oil is produced by thermal degradation in absence of oxygen. When particle size range from 5 to $50 \mathrm{~mm}$, temperature is lower than $400^{\circ} \mathrm{C}$ and residence time is longer than 30 $\mathrm{min}$, it is consider slow pyrolysis. This produces almost same fractions of liquid, char and gas. For small particles $(<1 \mathrm{~mm})$ at moderate temperature $\left(500^{\circ} \mathrm{C}\right)$, with contact residence time from 10 to $20 \mathrm{~s}$, a fast pyrolysis occurs, producing higher aqueous fraction. Finally, at short residence time (1s) of small particles $(<0.2 \mathrm{~mm})$, a flash pyrolysis takes place, producing high aqueous fraction $(75 \%)$, followed by gas fraction (13\%) [35,40]. Carbon monoxide, alkanes, alkenes, phenolformaldehyde resins and carboxylic acids are byproducts of pyrolysis [44].

\section{Bio-Refinery}

Dermibas and Dermibas [8] described bio-refinery as a facility that integrates biomass conversion process and equipment to produce fuels, power, and value-added chemicals from biomass with minimal waste and emissions. In addition, food and natural products production are also included in the bio-refinery concept $[47,48]$. In a broad definition, bio-refineries convert all kinds of biomass (all organic residues, energy crops, and aquatic biomass) into numerous products (fuels, chemicals, power and heat, materials, and food) (Figure 1). Microalgae can easily be part of this concept since each species produces certain amount of lipids, carbohydrates or proteins which biomass can be used in different process. Microalgae lipids can be used as feedstock for biodiesel production or omega 3 and 6 fatty acids (described in the next section) for human consumption. Bioethanol from starch can be produced. As well, carbohydrates as starch, glucose, sugars and other polysaccharides, have high overall digestibility for food or feeds [49]. The high protein content of some algae species is one of the main reasons to consider them as a non-conventional source of protein. However, information on the nutritive value of the protein and the degree of availability of the amino acids should be given [49]. Once algae biomass is free of this fraction, thermochemical conversion and biogas is possible (Figure 1).

\section{Challenges and Evaluation of Algae Fuels Sustainability}

Microalgae can grow either in open ponds or closed systems, called photobioreactors Algae cultures contamination represents another challenge since bacterial and protozoa growth can easily occurs [1], most commonly in open ponds. However, bacterial and zooplankton growth inhibition have been reported in $\mathrm{pH}$ of $11[1,50]$. High production rates in open ponds are achieved with algal strains resistant to severe culture environment conditions; for instance, Dunaliella, Spirulina and Chlorella sp. strains are cultivated in high salinity, alkalinity and nutrient restrictions [51,52]. In closed photobioreactors contamination can be reduced allowing better control of cultivation conditions and higher biomass productivities [51,53]. In addition, photobioreactors require less space, water lose by evaporation is lower and they possess higher efficiency capture of $\mathrm{CO}_{2}$ from the atmosphere. However, cooling and heating systems are required to control the cultivation temperature [54].

Life Cycle Assessment (LCA) is a compilation and evaluation of the inputs, outputs and the potential environmental impacts of a product system throughout its life cycle [55]. LCA based on biofuels has been done with no profitable results due to the economic and environmental impact. Particularly in microalgae biofuels, LCA debate focus on life-cycle impacts of large-scale production, especially the impact on water usage, energy inputs, inorganic salts, phosphorous and nitrogen fertilizers (mainly produced from natural gas), methanol utilization for transesterification and glycerol production as co-product.

In case of cultivation, microalgae needs high fertilizer inputs (mainly nitrogen), which are responsible for a significant production of GHG emissions [56]. Fenton et al., [57] proposed the use of surplus agricultural manures in their raw state, by-products of anaerobic digestion, runoff and artificial drainage waters as nutrient suppliers for algae cultures. Since anaerobic digestion of agricultural manures passes thru a pasteurization step, the slurry represents a safe option for algae cultures. However sampling and nutrient analysis of all manures should be carried to ensure correct utilization. In case of manures utilization, pretreatment or dilution could be needed to allow light penetration. Also, storage conditions to avoid nitrogen and phosphorus losses by volatilization and precipitation, respectively should be assessed [57].

Microalgae harvesting is also one of the major challenges since its energy intensive; gravity sedimentation is preferred, however is low efficient and time consuming, while efficient centrifugation requires high energy input [1]. In addition algae biomass dewatering can represent a $90 \%$ of the total energy consumption in the process [58]. However, ultrasonic harvesting, cross-flow membrane filtration, electrocoagulation or electrolytic aggregation and wet hexane extraction via the Valico process, represent a low-energy and low-cost harvesting and extraction methods [59].

In order to contribute to the reduction of energy consumption of algae biofuel process, different practices have been proposed. When microalgae are grown in sea water or wastewater, biodiesel production may consume much less potable water than conventional feedstockbased biodiesel production. In addition, other alternatives are (1) production of ethanol from algae starch after oil extraction, (2) usage of glycerol and residual biomass for energy conversion, (3) wastewater usage and water recycling once biomass was harvested, (4) cell wall disruption pretreatment to enhance oil extraction, (5) $\mathrm{pH}$ adjustment with biological flocculants to aid harvesting and (6) use of solar heat for drying [55,56,60,61]. In addition, other technologies to produce biofuels from algae have been proposed (pyrolysis, liquefaction). These technologies do not require the extraction of algae fractions by utilization of all biomass.

For bio-hydrogen production, more studies on the enhancement 
of hydrogen production are needed [36]. In case of chemical processes to produce bio-oil and biogas, diverse challenges are faced. As example for biogas production algae have a low $\mathrm{C} / \mathrm{N}$ ratio, ammonia production that inhibits the process. In addition, algae cell walls are not easily degraded by bacteria. Therefore pretreatments to release cell material o brake cell walls are required [37]. In case of HTL and pyrolysis, reaction pathways and kinetics require deeper study $[35,45]$. However, advantages of HTL and catalytic hydrothermal gasification (CHG) include: capture of $85 \%$ of the carbon in algae as fuel-grade component (bio-oil that can be upgraded to diesel, jet, gasoline and syngas), wastewater treatment to reduce the organic content, methane source for process energy and recycle of water and nutrients for algal cultivation.

Finally, genetic modifications have also being addressed in order to enhance biomass and metabolites productivities [62]. In case of cyanobacteria new processes by genetic modifications are being assessed to produce ethanol or hydrocarbons directly and continuously from the cells themselves [59]. However, there is a need to develop standards and regulatory protocols for the use of genetically modified algae [62]

\section{Other applications}

High value compounds: The main components of the algae lipid fraction are fatty acids (FA), waxes, sterols, hydrocarbons, ketones and pigments (carotenoids, chlorophylls, phycobilins) [63]. Some species of freshwater and marine algae contain large amounts of PUFAs [64]. These include the $\alpha$ - Linolenic acid (ALA 18:3 $\omega$-3), $\gamma$-Linolenic acid (GLA, 18:3 $\omega-6$ ), eicosapentaenoic acid (EPA, 20:5 $\omega-3$ ), arachidonic acid (ARA, 20:6 $\omega-6)$ docosapentaenoic acid (DPA, 22:5 $\omega-3$ ) and docosahexaenoic acid (DHA, 22:6 $\omega-3)$ [65,66]. According to AdarmeVega [67] these long chain $\omega-3$ PUFAs provide significant health benefits particularly in reducing cardiac diseases such as arrhythmia, stroke and high blood pressure. As well, they have beneficial effects against depression, rheumatoid arthritis, asthma and can be used for treatment of inflammatory diseases such as rheumatoid arthritis, Crohn's disease, ulcerative colitis, psoriasis, lupus and cystic fibrosis.

Natural pigments have an important role in the photosynthetic and pigmentation metabolism of algae, and also exhibit several beneficial biological activities like antioxidant, anti-carcinogenic, anti-inflammatory, anti-obesity, anti-angiogenic and neuroprotective $[68,69]$. The three basic classes of natural pigments found in marine algae are chlorophylls, carotenoids and phycobiliproteins.

Wastewater treatment: Different studies have tested microalgae strains with diverse wastewater effluents. Chojnacka et al., [70] reported that Spirulina sp. is able to absorb heavy metal ions $\left(\mathrm{Cr}^{3+}, \mathrm{Cd}^{2+}\right.$, and $\mathrm{Cu}^{2+}$ ) from wastewater. According to the wastewater characteristics (suspended solids, $\mathrm{pH}$, biodegradability), different algae strains should be chosen. Chen et al., [71] treated animal wastewater for nutrient removal with Chlorella sp. and remediation of textile wastewater by Chlorella vulgaris has also been reported [72]. Mezzomo et al., [73] treated swine waste water with Spirulina platensis and Mata et al., [74] used Scenedesmus obliquus for brewery wastewater. Results showed removal efficiencies from 60 to $80 \%$.

Fertilizers: In case of fertilizers, marine macroalgae and cyanobacteria are commonly used [75-77]. Macro algae are source of nitrogen, minerals, salts and carbon [78]. In case of cyanobacteria, some species as Anabaena azollae [79], are capable to fix nitrogen from the air, providing this nutrient to the plant roots [80]. Studies of cyanobacteria as fertilizers became important when these microorganism were found in rice fields $[81,82]$. Currently, other crops are evaluated with the use of cyanobacteria as bio-fertilizers [8385]. Microalgae direct usage as fertilizer is not commonly reported. However, Han et al., [78], proposed compost from microalgae (and macro algae) to ensure utilization of cell's nutrients by the soil.

\section{Conclusions}

Around the world, many research centers and companies are developing technology process and products from these microorganisms. Some advantages from microalgae are:

- Technologybased in these microorganisms currently represents an opportunity for GHG reduction from anthropogenic activities.

- Biofuels as biodiesel, bioethanol, bio-oil, bio-hydrogen or biogas can be produced. Decreasing political and economic pressure of some countries.

- Biomass can be produced in areas that cannot support agriculture. Avoiding deforestation and change of land use.

- Wastewater can be used in algae systems as source of nitrogen and phosphorous. Biomass can be further used as fertilizers.

- Species are source of products needed in human nutrition: DHA, EPA, antioxidants, proteins.

- Algae biomass can be used as feedstock for bio-refineries to produce different kinds of products (energy, food, plastics, and fertilizers).

However, how far is current technology from algae production at big scale? First evaluation of algae utilization for biofuels production was reported by Sheehan et al., [86] in the work titled as "A Look Back at the U.S. Department of Energy's Aquatic Species Program: Biodiesel from Algae". The authors concluded that algae technology faced different challenges, mainly based in low biomass productivity. Therefore by that time, biofuels production from algae was not feasible. Currently, biofuels from algae are strongly criticized based on the impact of energy, water, and petroleum-based products needed in the production process (as methanol, catalyst) or the produced after the process (glycerol).

Most of the world companies commercializing products from algae started producing fuels for the transport sector (biodiesel, jet fuel). However, production process is not economically competitive with petroleum-based fuels. Therefore, economic incentives are needed, besides low price feedstock's and low price processing. Facing this situation, these companies are also investing in the production of other compounds with high price commercialization, pigments and fatty acids. Since species are source of proteins, fatty acids (needed for proper body functions) and pigments (used for chemistry purposes), companies have focus in technology developing based in the production, extraction and purifications of these compounds. Currently, these products have high demand and commercialization price. However, research is needed to reduce product losses during purification steps.

In order to contribute to the reduction of energy consumption of algae biofuels process, different practices have been proposed:

- Microalgae culture in sea water or wastewater to reduce consuming of potable water. 
- Production of ethanol from algae starch once oil for biodiesel has been extracted. Same for other fuels technologies (biogas, bio-oil).

- Reutilization of glycerol and residual biomass for energy conversion as pyrolysis or biogas.

- Water recycling once biomass has been harvested.

- Cell wall disruption pretreatment to enhance products extraction.

- $\mathrm{pH}$ adjustment with biological flocculants to aid harvesting.

- Utilization of solar energy and heat for drying.

In the NAABB 2013 research report [59] it is concluded that algae technology should focus in the developing of algal strains with enhanced growth characteristic and biofuel productivity. Also, land requirements for algae cultivation should be assessed in order to inform the potential amount of biofuels to be produced. However, improvements in culture systems and HTL of Chlorella sp. DOEE1412 can decrease from more than $\$ 200$ USD per gallon to less than $\$ 8$ USD per gallon of bio-crude compared to the traditional raceway, centrifuge, wet extraction and conversion pathway.

Even for biofuels production or high price compounds, more research is needed to assess big scale production. Both products need extraction or purification processes. Therefore, reduction of product losses during purification steps is required. Currently, to increase production yields in these microorganisms genetic modifications are been assessed, either to produce lipids for biofuels or other compounds. However, culture growth conditions (temperature, nutrients, light) must still be evaluated to increase the amount of specific compounds produced by the microorganisms. In addition, growth conditions should be tested to simulate outdoor culture conditions. Finally, studies in long term stability of algae products should be evaluated. Pigments are easily degraded due to temperature, light or other microorganisms, while PUFAs oxidize by desaturation. Therefore studies with additives or preservatives in extracts should be carried. However, microalgae are living microorganism that represent a huge opportunity in research fields and process developing, reason why algae community (researchers and companies) is widespread all around the world.

\section{Acknowledgment}

The authors thank to Legado Base de la Piramide Program and Chair of Bioprocesos Ambientales from Tecnologico de Monterrey for the support and assistance provided during this investigation.

\section{References}

1. Rawat I, Ranjith Kumar R, Mutanda T, Bux F (2013) Biodiesel from microalgae: A critical evaluation from laboratory to large scale production. Appl Energy 103: 444-467.

2. Batista AP, Gouveia L, Bandarra NM, Franco JM, Raymundo A (2013) Comparison of microalgal biomass profiles as novel functional ingredient for food products. Algal Res 2: 164-173.

3. Mendes RL, Nobre BP, Cardoso MT, Pereira AP, Palabra AF (2003) Supercritical carbon dioxide extraction of compounds with pharmaceutical importance from microalgae. Inorganica Chim Acta. 356: 328-334.

4. Perez-Garcia O, Escalante FME, de-Bashan LE, Bashan Y (2011) Heterotrophic cultures of microalgae: Metabolism and potential products. Water Res 45: 1136.

5. Brennan L, Owende P (2010) Biofuels from microalgae-A review of technologies for production, processing, and extractions of biofuels and coproducts. Renew Sustain Energy. 4: 557-577.
6. Alam F, Date A, Rasjidin R, Saleh M, Moria H, et al. (2012) Biofuel from AlgaeIs It a Viable Alternative? Procedia Eng 49: 221-227.

7. Singh A, Olsen SI (2011) A critical review of biochemical conversion sustainability and life cycle assessment of algal biofuels. Appl Energy 88: 3548-3555.

8. Demirbas A, Demirbas MF (2010) Algae Energy: Algae as a New Source of Biodiesel, Green Ener. Springer

9. Cuellar-Bermudez SP, García-Perez JS, Rittmann BE, Parra-Saldivar R (2014) Photosynthetic Bioenergy Utilizing CO2: an approach on flue gases utilization for third generation biofuels. J Clean Prod. doi:10.1016/j.jclepro.2014.03.034.

10. Yang H, Xu Z, Fan M, Gupta R, Slimane R, et al. (2008) Progress in carbon dioxide separation and capture: A review. J Environ Sci 20: 14-27.

11. Spigarelli BP, Kawatra SK (2013) Opportunities and challenges in carbon dioxide capture. J CO2 Util 1: 69-87.

12. Ho S, Chen C, Lee D, Chang J (2011) Perspectives on microalgal CO 2 -emission mitigation systems - A review. Biotechnol Adv 29: 189-198.

13. Skjånes K, Lindblad P, Muller J (2007) BioCO2 - A multidisciplinary, biological approach using solar energy to capture $\mathrm{CO} 2$ while producing $\mathrm{H} 2$ and high value products. Biomol Eng 24: 405-413.

14. Acién Fernández FG, González-López C V, Fernández Sevilla JM, Molina Grima E (2012) Conversion of CO2 into biomass by microalgae: how realistic a contribution may it be to significant $\mathrm{CO} 2$ removal? Appl Microbiol Biotechnol 96: $577-86$.

15. Costa JAV, Linde GA, Atala DIP, Mibielli GM, Krüger TR (2000) Modelling of growth conditions for cyanobacterium Spirulina platensis in microcosms. World J Microbiol Biotechnol 16: 15-18.

16. Vasudevan PT, Fu B (2010) Environmentally Sustainable Biofuels?: Advances in Biodiesel. Waste Biomass Valor 1: 47-63.

17. Knothe Gerhard, Dunn Robert O., Bagby Marvin O. (1997) Biodiesel:The Use of Vegetable Oils and Their Derivatives as Alternative Diesel Fuels. American Chemical Society, Washington, DC

18. Dunn RO, Knothe G, Bagby M. (1997) Recent advances in the development of alternative diesel fuel from vegetable oil and animal fats. Recent Res Dev Oil Chem 1: 31-56.

19. Knothe G (2001) Analytical methods used in the production and fuel quality assessment of biodiesel. Am Soc Agric Eng 44: 193-200.

20. Borges ME, Díaz L (2012) Recent developments on heterogeneous catalysts for biodiesel production by oil esterification and transesterification reactions: A review. Renew Sustain Energy Rev 16: 2839-2849.

21. Chen Y, Xiao B, Chang J, Fu Y, Lv P, et al. (2009) Synthesis of biodiese from waste cooking oil using immobilized lipase in fixed bed reactor. Energy Convers Manag 50: 668-673.

22. Guerreiro L, Pereira PM, Fonseca IM, Martin-Aranda RM, Ramos AM, et al. (2010) PVA embedded hydrotalcite membranes as basic catalysts for biodiese synthesis by soybean oil methanolysis. Catal Today 156: 191-197.

23. Ma F, Hanna MA (1999) Biodiesel production: a review. Bioresour Technol 70: 1-15.

24. Khan SA, Rashmi, Hussain MZ, Prasad S, Banerjee UC (2009) Prospects of biodiesel production from microalgae in India. Renew Sustain Energy Rev 13 2361-2372.

25. Leung DYC, Wu X, Leung MKH (2010) A review on biodiesel production using catalyzed transesterification. Appl Energy 87: 1083-1095.

26. Lam MK, Lee KT, Mohamed AR (2010) Homogeneous, heterogeneous and enzymatic catalysis for transesterification of high free fatty acid oil (waste cooking oil) to biodiesel: a review. Biotechnol Adv 28: 500-18.

27. González AF, Jiménez IC, Rodriguez M, Restrepo S, Gómez JM (2008) Biocombustibles de segunda generación y biodiesel: una mirada a la contribución de la Universidad de los Andes. Rev Ing 28: 70-82.

28. Math MC, Kumar SP, Chetty S V. (2010) Technologies for biodiesel production from used cooking oil - A review. Energy Sustain Dev 14: 339-345.

29. Vicente G, Martínez M, Aracil J (2004) Integrated biodiesel production: a comparison of different homogeneous catalysts systems. Bioresour Technol 92: 297-305. 
Citation: Cuellar-Bermudez SP, Romero-Ogawa MA, Rittmann BE, Parra-Saldivar R. Algae Biofuels Production Processes, Carbon Dioxide Fixation and Biorefinery Concept. J Pet Environ Biotechnol 5: 185. doi:10.4172/2157-7463.1000185

30. Guschina IA, Harwood JL (2006) Lipids and lipid metabolism in eukaryotic algae. Prog Lipid Res 45: 160-186.

31. Bart J, Palmeri N, Cavallaro S (2010) Biodiesel Science and Technology: From Soil to Oil. Woodhead Publishing Series in Energy, Washington, DC

32. Chisti Y (2007) Biodiesel from microalgae. 25: 294-306.

33. Das D, Veziroglu T (2008) Advances in biological hydrogen production processes. Int J Hydrogen Energy

34. Gouveia L, Oliveira AC (2009) Microalgae as a raw material for biofuels production. J Ind Microbiol Biotechnol 36: 269-74.

35. Marcilla A, Catalá L, García-Quesada JC, Valdés FJ, Hernández MR (2013) A review of thermochemical conversion of microalgae. Renew Sustain Energy Rev 27: 11-19.

36. Oncel SS (2013) Microalgae for a macroenergy world. Renew Sustain Energy Rev 26: 241-264.

37. Ramos-Suárez JL, Carreras N (2014) Use of microalgae residues for biogas production. Chem Eng J 242: 86-95.

38. Demirbas MF (2011) Biofuels from algae for sustainable development. Appl Energy 88: 3473-3480.

39. Suali E, Sarbatly R (2012) Conversion of microalgae to biofuel. Renew Sustain Energy Rev 16: 4316-4342.

40. Brennan L, Owende P (2010) Biofuels from microalgae - A review of technologies for production, processing, and extractions of biofuels and coproducts. 14: 557-577.

41. Ward AJ, Lewis DM, Green FB (2014) Anaerobic digestion of algae biomass: A review. Algal Res.

42. Golueke CG, Oswald WJ, Gotaas HB (1957) Anaerobic digestion of Algae Appl Microbiol 5: 47-55.

43. Parkin GF, Owen WF (1986) Fundamentals of Anaerobic Digestion of Wastewater Sludge. J Environ Eng 112: 867-920.

44. Ghasemi Y, Rasoul-Amini S, Naseri AT, Montazeri-Najafabady N, Mobasher MA, et al. (2012) Microalgae biofuel potentials (Review). Appl Biochem Microbiol 48: 126-144

45. López Barreiro D, Prins W, Ronsse F, Brilman W (2013) Hydrotherma liquefaction $(\mathrm{HTL})$ of microalgae for biofuel production: State of the art review and future prospects. Biomass and Bioenergy 53: 113-127.

46. Peterson AA, Vogel F, Lachance RP, Fröling M, Antal MJ, et al. (2008) Thermochemical biofuel production in hydrothermal media: A review of suband supercritical water technologies. Energy Environ Sci 1: 32.

47. Yen H-W, Hu I-C, Chen C-Y, Ho SH, Lee DJ, et al. (2013) Microalgae-based biorefinery--from biofuels to natural products. Bioresour Technol 135: 166-74.

48. Vanthoor-Koopmans M, Wijffels RH, Barbosa MJ, Eppink MHM (2013) Biorefinery of microalgae for food and fuel. Bioresour Technol 135: 142-9.

49. Spolaore P, Joannis-Cassan C, Duran E, Isambert A (2006) Commercial applications of microalgae. J Biosci Bioeng 101: 87-96.

50. Park JBK, Craggs RJ, Shilton AN (2011) Wastewater treatment high rate algal ponds for biofuel production. Bioresour Technol 102: 35-42.

51. Harun R, Singh M, Forde GM, Danquah MK (2010) Bioprocess engineering of microalgae to produce a variety of consumer products. Renew Sustain Energy Rev 14: 1037-1047.

52. Lee $Y$ (2001) Microalgal mass culture systems and methods?: Their limitation and potential. J APPL PHYCOL 13: 307-315.

53. Grobbelaar JU (2008) Factors governing algal growth in photobioreactors: the "open" versus "closed" debate. J Appl Phycol 21: 489-492.

54. Pires JCM, Alvim-Ferraz MCM, Martins FG, Simões M (2012) Carbon dioxide capture from flue gases using microalgae: Engineering aspects and biorefinery concept. Renew Sustain Energy Rev 16: 3043-3053.

55. Pfromm PH, Amanor-Boadu V, Nelson R (2011) Sustainability of algae derived biodiesel: A mass balance approach. Bioresour Technol 102: 1185-1193.

56. Handler RM, Canter CE, Kalnes TN, et al. (2012) Evaluation of environmenta impacts from microalgae cultivation in open-air raceway ponds: Analysis of the prior literature and investigation of wide variance in predicted impacts. Algal Res 1: 83-92.
57. Fenton O, Ó hUallacháin D (2012) Agricultural nutrient surpluses as potential input sources to grow third generation biomass (microalgae): A review. Algal Res 1: 49-56.

58. Xu L, Wim Brilman DWF, Withag JAM, Brem G, Kersten S (2011) Assessment of a dry and a wet route for the production of biofuels from microalgae: energy balance analysis. Bioresour Technol 102: 5113-22.

59. NAABB (2013) National Alliance for Advanced Biofuels and Bio-products Report.

60. Yang J, Xu M, Zhang X, Hu Q, Sommerfield M, et al. (2011) Life-cycle analysis on biodiesel production from microalgae: Water footprint and nutrients balance. Bioresour Technol 102: 159-165.

61. Lardon L, He'lias A, Sialve B, Steyer JP, Bernard O (2009) Life-Cycle Assessment of Biodiesel Production from Microalgae. Environ Sci Technol 43 6475-6481.

62. DODGE E (2014) CO2 to Fuels via Photosynthesis. In: Break. Energy.

63. Halim R, Gladman B, Danquah MK, Webley PA (2011) Oil extraction from microalgae for biodiesel production. Bioresour Technol 102:178-85.

64. Guschina IA, Harwood JL (2006) Lipids and lipid metabolism in eukaryotic algae. Prog Lipid Res 45: 160-86

65. Fraeye I, Bruneel C, Lemahieu C, Buyse J, Muylaert K, et al. (2012) Dietary enrichment of eggs with omega-3 fatty acids: A review. Food Res Int 48: 961-969.

66. Ryckebosch E, Bruneel C, Muylaert K, Foubert I (2012) Microalgae as an alternative source of omega-3 long chain polyunsaturated fatty acids. Lipid Technol 24: 128-130.

67. Adarme-Vega TC, Lim DKY, Timmins M, Vernen F, Li Y, et al. (2012 Microalgal biofactories: a promising approach towards sustainable omega-3 fatty acid production. Microb Cell Fact 11: 96.

68. Pangestuti R, Kim S-K (2011) Biological activities and health benefit effects of natural pigments derived from marine algae. J Funct Foods 3: 255-266.

69. Guedes AC, Amaro HM, Malcata FX (2011) Microalgae as sources of carotenoids. Mar Drugs 9:625-44.

70. Chojnacka K, Chojnacki A, Górecka H (2005) Biosorption of Cr3+, Cd2+ and $\mathrm{Cu} 2+$ ions by blue-green algae Spirulina sp.: kinetics, equilibrium and the mechanism of the process. Chemosphere 59: 75-84

71. Chen R, Li R, Deitz L, Liu Y, Stevenson J, et al. (2012) Freshwater algal cultivation with animal waste for nutrient removal and biomass production. Biomass and Bioenergy 39: 128-138.

72. Lim S-L, Chu W-L, Phang S-M (2010) Use of Chlorella vulgaris for bioremediation of textile wastewater. Bioresour Technol 101:7314-7322.

73. Mezzomo N, Galon Saggiorato A, Siebert R, Tatsch PO, Lago MC, et al. (2010) Cultivation of microalgae Spirulina platensis (Arthrospira platensis) from biological treatment of swine wastewater. Ciência e Tecnol Aliment 30 : 173-178.

74. Mata TM, Melo AC, Simões M, Caetano NS (2012) Parametric study of a brewery effluent treatment by microalgae Scenedesmus obliquus. Bioresour Technol 107: 151-8

75. Singh JS, Pandey VC, Singh DP (2011) Efficient soil microorganisms: A new dimension for sustainable agriculture and environmental development. Agric Ecosyst Environ 140: 339-353.

76. Benemann JR (1979) Production of nitrogen fertilizer with nitrogen-fixing blue green algae. Enzyme Microb Technol 1: 83-90.

77. Tripathi RD, Dwivedi S, Shukla MK, Mishra S, Srivastava S, et al. (2008) Role of blue green algae biofertilizer in ameliorating the nitrogen demand and fly-ash stress to the growth and yield of rice (Oryza sativa L.) plants. Chemosphere 70: 1919-29.

78. Han W, Clarke W, Pratt S (2014) Composting of waste algae: A review. Waste Manag.

79. Bocchi S, Malgioglio A (2010) Azolla-Anabaena as a Biofertilizer for Rice Paddy Fields in the Po Valley, a Temperate Rice Area in Northern Italy. Int J Agron 5 pages.

80. Kahindi JHP, Woomer P, George T, de Souza FM, Karanja NK, et al. (1997) Agricultural intensification, soil biodiversity and ecosystem function in the tropics: the role of nitrogen-fixing bacteria. Appl Soil Ecol 6: 55-76. 
Citation: Cuellar-Bermudez SP, Romero-Ogawa MA, Rittmann BE, Parra-Saldivar R. Algae Biofuels Production Processes, Carbon Dioxide Fixation and Biorefinery Concept. J Pet Environ Biotechnol 5: 185. doi:10.4172/2157-7463.1000185

Page 8 of 8

81. Pereira I, Ortega R, Barrientos L, Moya M, Reyes G, et al. (2008) Development of a biofertilizer based on filamentous nitrogen-fixing cyanobacteria for rice crops in Chile. J Appl Phycol 21: 135-144.

82. Mishra U, Pabbi S (2004) Cyanobacteria: A potential biofertilizer for rice. Resonance 9: 6-10.

83. Karthikeyan N, Prasanna R, Nain L, Kaushik BD (2007) Evaluating the potential of plant growth promoting cyanobacteria as inoculants for wheat. Eur $\mathrm{J}$ Soil Biol 43: 23-30.

84. Svircev(Obreht) Z, Tamas I, Nenin P, Drobac A (1997) Co-cultivation of N2fixing cyanobacteria and some agriculturally important plants in liquid and sand cultures. Appl Soil Ecol 6: 301-308.
85. Aseri GK, Jain N, Panwar J, Rao AV, Meghwal PR (2008) Biofertilizers improve plant growth, fruit yield, nutrition, metabolism and rhizosphere enzyme activities of Pomegranate (Punica granatum L.) in Indian Thar Desert. Sci Hortic (Amsterdam) 117: 130-135.

86. Sheehan J, Dunahay T, Benemann J, Roessler P (1998) Look Back at the U.S. Department of Energy's Aquatic Species Program: Biodiesel from Algae; Close-Out Report, National Renewable Energy Laboratory, USA 